\title{
1 The Effects of Thinning and Burning on Understory Vegetation in North America: A Meta- 2 Analysis
}

4 Joshua Willms ${ }^{1}$, Anne Bartuszevige ${ }^{2}$, Dylan W. Schwilk ${ }^{1}$, and Patricia L. Kennedy ${ }^{3}$

$5 \quad{ }^{1}$ Texas Tech University, Department of Biological Sciences

$6 \quad{ }^{2}$ Playa Lakes Joint Venture, Lafayette, CO 80026

$7 \quad{ }^{3}$ Eastern Oregon Agriculture \& Natural Resource Program and Department of Fisheries and Wildlife, Oregon State University, Union, OR 97883. Corresponding Author:

$9 \quad$ pat.kennedy@ oregonstate.edu

\section{ABSTRACT}

12 Management in fire-prone ecosystems relies widely upon application of prescribed fire and/or fire13 surrogate (e.g., forest thinning) treatments to maintain biodiversity and ecosystem function. The 14 literature suggests fire and mechanical treatments proved more variable in their effects on understory 15 vegetation as compared to their effects on stand structure. The growing body of work comparing fire and 16 thinning effects on understory vegetation offers an opportunity to increase the generality of conclusions 17 through meta-analysis. We conducted a meta-analysis to determine if there were consistent responses of 18 understory vegetation to these treatments in North American forests that historically experienced 19 frequent surface fire regimes ( $<20$ years fire return interval, FRI). Means and standard errors were extracted from 32 papers containing data on the response of four understory functional groups

21 (herbaceous, shrub, non-native, and total) to thinning and burning treatments to calculate effect sizes.

22 Lack of replication and inconsistent reporting of results hindered our ability to include many studies in 23 this analysis. For each response variable (species richness and percent cover), we compared three 24 treatment pairs: burn vs control, thin vs control and thin vs burn. We calculated standardized mean 25 differences (Hedges' $\mathrm{g}$ ) for each pair and tested if this differed from zero using a random effects model 26 fit with restricted maximum likelihood to account for variation by site. The most consistent effect of the 
treatments was the increase in non-native species following mechanical thinning and reduction in shrub

28 cover following a burn. These differences suggest the two treatments may not be surrogates in the shortterm (less than 5 years). Increase of non-native species due to disturbance is well established but it is not

30 clear if burning and thinning consistently have differential impacts. Response of non-native plants to

31 disturbance is likely a complex function of a variety of site and landscape factors that cannot be evaluated by the current literature. We conclude that prescribed fire and thinning treatments can be used successfully to restore understory species richness and cover, but they can create different conditions and these potentially different outcomes need to be considered in the planning of a fuels reduction treatment. We discuss management options to reduce negative effects of the treatments and we suggest managers use current decision-making frameworks prior to designing an intervention. Keywords: burning, disturbance, fire surrogates, forest understory, fuels reduction, meta-analysis, non38 native understory vegetation, thinning

\section{Introduction}

North American frequent-fire forests have been shaped by fire over evolutionary and ecological time scales. However, for much of the 20th century, land managers concentrated on minimizing amount of

42 land that burned. Compared to presettlement fire regimes in many contemporary forests, fire intervals 43 have lengthened (Cyr et al. 2009, Aldrich et al. 2010, Spetich et al. 2011), although there is evidence for 44 significant variability in historical fire return intervals (Odion et al. 2014). Increased recognition of the 45 central role of fire in maintaining forest structure and function has contributed to a shift from fire exclusion to reintroduction of fire in fire-dependent forests, with the aim of reducing fuels and restoring historic stand structure (Agee and Skinner 2005). This recognition has prompted U. S. federal initiatives such as the National Fire Plan and Healthy Forest Restoration Act (2003) that mandate federal land managers restore forest structure and function and reduce risk of wildfire on federal lands. Use of widespread (i.e., over a large area) fuel treatments has led to increasing discussion of the effectiveness,

51 suitability and ecological impacts of thinning and prescribed fire (Schoennagel et al. 2004, Schwilk et al. 2009, Schoennagel and Nelson 2011, Stephens et al. 2013). 
53 Although prescribed fire is often the preferred fuel reduction practice, forest managers often face social 54 and economic constraints on burning particularly when human safety and property might be compromised. Additionally, in forests thought to have departed significantly from historical fire return intervals, there is concern that introducing fire may result in unnaturally high intensity fire that may be 57 difficult to manage or may have negative ecological effects (but see Bond et al. 2012 and Fontaine and Kennedy 2012). Therefore, mechanical fuel reduction methods have increasingly been used to reduce fuels or restore historic stand structure (Crow and Perera 2004). Uncertainty regarding the relative

60 ecological effects of prescribed fire versus mechanical treatments has led to increasing attention on these 61 so-called "fire surrogates" such as the National Fire and Fire Surrogate study (Schwilk et al. 2009, 62 McIver et al. 2013).

63 Early forest management emphasized recruiting trees for commercial harvest. However, in the last half 64 of the 20th century, forest management practices have shifted focus to include managing for ecosystem services, including biodiversity. In most forests, the majority of plant biodiversity is in the understory herbaceous layer. In addition to harboring high diversity, understory herbaceous communities have profound effects on other ecosystem services such as forest nutrient cycling (reviewed by Gilliam 2007). Most attention has been paid to the effects of fire and mechanical treatments on forest structure and fuels (e.g., Moghaddas et al 2008, van Mantgem et al 2011, Kreye and Kobziar 2015, and reviewed in Fulé et al 2012); the extent to which mechanical treatments or thinning approximate effects of prescribed fire on forest understory vegetation is not as well understood. Results from the National Fire and Fire Surrogate study demonstrated that fire and mechanical treatments proved more variable in their effects on understory vegetation as compared to stand structure (Schwilk et al. 2009). This is not entirely surprising: although both fire and thinning remove overstory trees and allow increased light to reach understory plants, extent of canopy removal varies with thinning intensity and fire severity. According to a recent review by Abella and Springer (2015) treatments must reduce tree canopy cover to <30-50\% to elicit appreciable responses from the forest understory.

In addition to variable treatment effects on forest cover, fire and thinning modify the abiotic environment differently. Fire restructures microsites and soils that many plants depend on for germination and growth (Bond and van Wilgen 1996, Gundale et al. 2005, 2006, DeLuca et al. 2006). 
81 Thinning, on the other hand, removes or rearranges (as opposed to consumes) vegetation and may alter 82 nutrient dynamics (e.g., Boerner et al. 2006). Many mechanical thinning methods also result in soil 83 disturbance and compaction that fire does not cause (Schwilk et al. 2009). The differences exhibited 84 between fire and fire surrogate treatments may result in differences in responses between native and 85 nonnative species, and in the percent cover and species richness in the herbaceous and shrub layers 86 (Dodson 2004, Wienk et al. 2004, Metlen and Fiedler 2006, Collins et al. 2007, Nelson et al. 2008, 87 Zhang et al. 2008b, Fornwalt and Kaufmann 2014). The growing body of work comparing fire and 88 thinning effects on understory vegetation (recently reviewed by Abella \& Springer 2015 for mixed conifer forests in North America) offers an opportunity to increase the generality of conclusions through 90 meta-analysis.

91 Our objective was to conduct a meta-analysis of the literature that investigated effects of thin and burn 92 treatments on understory species in North American. Specifically, we were interested in the degree to 93 which thin treatments mimic prescribed burn treatments, and to what extent burning or thinning differ

94 from control treatments. We tested three pairwise comparisons: thinning treatments versus controls, 95 burning treatments versus controls, and thinning treatments versus burning treatments for percent cover 96 and species richness in total species, exotic species, herbaceous species, and shrub species.

97 We tested the following hypotheses: 1) total species richness and cover of herbaceous understory plants 98 will increase in thin and burn treatments compared to controls as an effect of increasing light availability 99 (Wienk et al. 2004, Metlen and Fiedler 2006, Fornwalt and Kaufmann 2014); 2) total cover of 100 understory shrubs will decrease in response to burning, but not to thinning in the short term because 101 burning consumes understory shrubs and these are slower to respond to increased light than are 102 herbaceous species (Nelson et al. 2008, Zhang et al. 2008b); and 3) non-native plant species are often 103 favored by disturbance and we expect both thinning and burning to increase non-native species richness 104 and cover relative to controls with the greatest increases in thinning treatments as a result of greater soil 105 disturbance in thinning relative to burning (Dodson 2004, Collins et al. 2007). 


\subsection{Literature Search and Vetting}

108 In May 2014, we performed a search of the scientific literature investigating effects of prescribed fire 109 and thinning treatments on understory vegetation. We used multiple databases: ISI Web of Science 110 (http://www.webofknowledge.com) and AGRICOLA (http://agricola.nal.usda.gov/) both of which 111 searched literature published since 1970 and Forest Science (http://www.cabi.org/forestscience/) which 112 searched literature published since 1939. We also supplemented these searches with a Google Scholar 113 search (http://scholar.google.com/) which, despite limitations in coverage, includes gray literature 114 publications as well as proceedings. In addition to these search engines, we included additional 115 references gleaned from publications found in the literature search.

116 We used the following search terms ( ${ }^{*}$ ' indicate wild card searches uses to include plural forms, etc.):

117 - Understory AND native*

118 - Percent Cover AND native*

119 - Fire AND Understory*

120 - Understory AND exotic*

121 - Percent Cover AND exotic*

122 - Fire AND Percent Cover*

123 • Understory AND forb*

- Percent Cover AND forb*

- Burn* AND Understory

126 - Understory AND graminoid*

- Percent Cover AND graminoid*

- Burn* AND Percent Cover

- Understory AND shrub*

- Percent Cover AND shrub*

- Thin* AND Understory 
134 The literature search from the databases yielded approximately 3,500 references, which were then vetted 135 for appropriate material. Documents were eliminated that dealt with medical issues (i.e., new treatments 136 for burn victims), investigations of ecological processes related to fire but not relevant to the scope of 137 this document (e.g., nutrient cycling, insect infestation), or modeling studies with little empirical data. 138 Because North American studies comprise the bulk of the literature and our power to examine larger 139 geographic patterns would be very low, we restricted our analyses to North America. We were 140 specifically interested in studies that collected quantitative data on the response of understory plants to a 141 prescribed fire or thinning treatment. We further narrowed our search to papers that specifically 142 compared thinning (understory or overstory) and prescribed fire. We excluded papers that only reported 143 the combined treatment of thinning and burning but did not include thinning or burning as separate 144 treatments. This vetting process yielded 57 references.

145 Because statistical reporting was not uniform across references, we performed a second round of vetting 146 to exclude papers that could not be placed in a quantitative meta-analysis. Papers that lacked replicated 147 treatments or failed to include a measure of variation (standard error, standard deviation or variance) 148 were excluded. In addition, studies that reported data collected 10 or more years after the thinning or 149 burning event were excluded because there wasn't sufficient literature to quantitatively examine long150 term effects of the treatments on understory vegetation. When multiple papers reported on the same 151 study (determined by location and study dates), we used only one of the published papers. Varying 152 levels of prescribed burn severity were inherent due to differences in species composition, terrain, 153 weather, and season. There were insufficient studies to quantitatively evaluate effects of burn severity on 154 understory vegetation. Thus, for studies that reported data for multiple levels of burning severity, the 155 moderate level of burning was selected for inclusion in this analysis. Varying forms of thinning and 156 mastication were used in thinning treatments. These included chainsaw, dragging a chain between 157 tractors, hand-thinning, thin-and-pile, thin-and-scatter, thin-only, thin-and-chip, partial-cut, and clear158 cut. Data were insufficient to quantitatively evaluate effects of various forms of thinning on understory 159 vegetation. Thus, for each paper that reported several types of thinning, data were selected that were as 160 close to a thin-only treatment as possible. If multiple thinning-only methods were used, we pooled data 161 across methods when possible. In some cases, separate papers reported results from the same 
162 experiment (e.g., Phillips et al 2007 and Waldrop et al 2008). In these cases, we did include both as 163 separate studies if they reported different response variables but we avoided including duplicated sites in 164 any particular contast.

\subsection{Data Extraction and Analysis}

166 We investigated effect of burning and thinning treatments on two response variables that describe effects 167 on understory vegetation: species richness and plant cover. Each of these was recorded separately for 168 each of two growth forms (herbaceous species and shrubs) and separately for exotic species and all 169 species combined. This resulted in four vegetative categories (herbaceous, shrub, non-native and total) 170 and two response types (cover and species richness) for a total of eight possible response variables, 171 although not all were available in each study. Although the shrub and herbaceous categories are 172 exclusive of one another, the other categories can overlap. For example, in several studies, non-native 173 species are a subset of herbaceous species. When plots at multiple spatial scales were included in a 174 study, we selected the scale closest to $100 \mathrm{~m}^{2}$ as this was the most commonly reported scale across 175 studies.

176 For each selected article, we extracted treatment means, sample size, and either standard deviations or 177 standard errors of the mean for each response variable from the results text, tables or figures as required. 178 In some cases, papers reported differences pre-post study and we used those differences rather than raw 179 richness and cover values. We calculated pairwise treatment effect sizes for each response variable for 180 three different pairwise comparisons: Thin vs Burn, Thin vs Control, and Burn vs Control. For each 181 comparison, we calculated the bias-adjusted estimate of the standardized mean difference ["Hedge's g", 182 a bias corrected version of Cohen's d (Gurevitch and Hedges 2001)] with the following equation:

(1) $g=\frac{X^{E}-X^{C}}{S^{E C}} J$

where $X^{E}$ is the mean value of the response variable in the "experimental treatment" (Burn or Thin 
188 is a term that corrects for bias due to small sample size (Gurevitch and Hedges 2001). The effect size, $g$,

189 can be interpreted as the difference between the cover or species richness of plants in treatments relative 190 to controls, measured in units of standard deviations.

191 We conducted all analyses in R (R Development Core Team 2013) using the metafor package

192 (Viechtbauer 2010). We assumed that true effect sizes varied across sites (treatments differ in details,

193 forests differ in absolute cover and richness, and plot sizes could vary) and therefore, we used a random-

194 effects models (Gurevitch and Hedges 2001). We parameterized models using restricted maximum-

195 likelihood. To test whether mean effect sizes for a comparison differed significantly from zero, we

196 assumed a normal distribution of effect sizes and their confidence intervals (Viechtbauer 2010). Because

197 of the large number of response variables and pairwise treatment comparisons, we used a Holm p-value

198 adjustment (sequential Bonferroni correction) to control for multiple comparison error rate. Our a priori

199 alpha-level was 0.1, which balanced the likelihoods of Type 1 and Type 2 errors.

200 A handful of compromises and assumptions were necessary to reconcile each reference into a single, 201 comparable format. When papers reported mean species richness or percent cover values and standard 202 errors for multiple years per treatment, we selected the data closest to the average years since treatment 203 for the overall data set (3 years). Because native species represented over $99 \%$ of species richness and 204 percent cover for papers in which both parameters were reported, 'native' was substituted for 'total' 205 species in cases where papers reported only 'native' (Collins et al. 2007, Dodson et al. 2007, and 206 Huffman et al. 2013).

207 The final data used to conduct this analysis were reported from a wide array of locations, forest types, 208 and ecological management histories (Table 1, Fig. 1). To account for this variation in sampling 209 methodologies and time-lines the following covariates were recorded: fire intensity, forest type, fuel 210 type, years since treatment, latitude, and longitude. We graphically explored the potential effects of 211 these covariates to detect potential interactions between these variables and our results. The only 212 covariate with explanatory power was longitude discretized as eastern vs western forests (east or west of 213 Longitude $100 \mathrm{West}$ ). Twenty-eight papers reported data from study sites in the western United States 214 and seven papers reported data from the eastern United States. We then ran all models using this discrete 215 factor, east vs west as a moderator variable and dropped it from the model when it was not significant. 
216 An important consideration in meta-analyses is the file drawer effect (e.g., Murtaugh 2002). This is the 217 bias due to the elevated rate of publication of statistically significant results and rejection of non218 significant results. We sampled across a wide range of sources (international to regional journals, 219 government publications), so the bias due to differential publication rates likely is minimal in the dataset 220 we assembled. Additionally, we expect publication bias to be less important for this meta-analysis than 221 for some others: for many of these studies, either fuel reduction or forest overstory restoration were the 222 major focus of the work and the purpose of the applied treatments. Therefore, we argue that little effect 223 on understory measures would not likely discourage publication. However, to assess prevalence of 224 publication bias we visually examined funnel plots for each response variable and contrast (Stern and 225 Egger 2001, Viechtbauer 2010). We expect high heterogeneity across studies because of different 226 methods and different measurement scales. To quantify heterogeneity, we calculated $\mathrm{I}^{2}$ :

$227 \quad I^{2}=100 \% \times(Q-d f) / Q$

228 where Q is Cochran's heterogeneity statistic (Cochran 1954) and df is degrees of freedom tested for 229 significant heterogeneity (Viechtbauer 2010). For comparisons with heterogeneity test p-values less 230 than 0.05 and $\mathrm{I}^{2}$ greater than $70 \%$, we removed the outlier studies. We defined outlier studies as those 231 outside the pseudo-confidence region with bounds $\theta \pm 1.96 S E$, where $\theta$ is the estimated effect or outcome 232 based on the fixed-effects model and $S E$ is the standard error value from the y-axis. For cases where 233 outliers existed, we confirmed that our conclusions regarding the significant effect of treatments did not 234 change after removal of the outlier, but all of our reported results include all available data even 235 including such putative outliers. 


\section{Results}

237 Our literature search and vetting resulted in 32 published studies. The length of time from treatment to 238 sampling ranged from 1 to 8 years (mean $=2.8$ years, median $=2$ years). Only one paper reported data 239 that were collected more than 5 years after treatment (Nelson et al. 2008). Although our search criteria 240 included North America, after vetting, only studies located in the USA remained and our results were 241 dominated by studies in the western US (26 western sites vs 6 eastern). Funnel plots for all comparisons 242 are supplied in Appendix 1 (all studies). Removing outliers as described did not change results - the 243 comparisons with outlier studies were comparisons in which the treatment effects were inconsistent. 244 Total species richness showed the greatest heterogeneity across sites (Appendix 1).

\subsection{Species Richness}

246 Non-native species richness was higher in thin treatments than in control treatments (Fig 2, adjusted p = $2470.001, \mathrm{~N}=7$ ), but this result is based entirely on western sites as no eastern thinning studies included 248 this variable. Although non-native species richness was higher in burning treatments than in controls 249 in all studies, this was not significant after Bonferroni correction (adjusted $p=0.116, \mathrm{~N}=6$ ).

250 Burning had a variable effect on total species richness (native and exotic) with increases relative to 251 controls at eastern, but not western sites (no main effect, latitude significant modifier, adjusted p = $2520.019, \mathrm{~N}=12$ ), but this result is based on 9 western and only 3 eastern sites (Fig. 3).

\subsection{Percent Cover}

254 Burning decreased percent cover of shrubs compared to controls (Fig. 4, adjusted p=0.014, $\mathrm{N}=7$ ).

255 There was no significant difference in shrub percent cover between thin and control treatments $(\mathrm{N}=7)$, 256 or between thin and burn treatments $(\mathrm{N}=6)$. The effect of thinning on total understory cover was 257 variable with little effect seen in most studies, but two eastern sites showed large negative effects of 258 thinning on cover. This effect was significant after multiple comparison correction but was based on 259 only these two eastern sites (Fig. 5, modifier $\mathrm{p}=0.043, \mathrm{n}=9$ ). 
260 There was no significant difference in non-native percent cover or herbaceous percent cover among any 261 of the treatment groups. However, very few (4) papers reported percent cover data for non-native 262 species (Table 1).

\section{4. Discussion}

264 Understory communities' response to fire and thinning was highly variable across the included studies 265 and few comparisons had mean differences significantly different from zero. Our prediction that total 266 species richness and herbaceous cover would increase in response to treatments was partially supported 267 by the analysis (e.g., species richness increased after burns in eastern forests). These results combined 268 with the Abella and Springer review (2015) suggest there is no consistent evidence that native herbaceous plants as a growth form respond to burning or thinning in the short-term. This does not mean that herbaceous understory plants do not respond to treatment, but it is likely there are species-specific responses that are lost when all taxa are lumped into the growth form category, herbaceous plants. We agree with Havill et al. (2015) and Keeley (2015) that future research needs to focus on developing a

273 better mechanistic understanding of the way in which trait variation within plant functional types affects 274 responses to disturbance. Pyke et al. (2010) provide one approach to predicting how fire will affect grassland plant populations that depends on the plant's life form and vital attributes for establishment and survival, and their interaction with fire regime. This approach could be expanded to predict responses of forest understory plants to both fire and thinning.

278 The most consistent effect of the treatments was the increase in non-native species following thinning 279 and reduction in shrub cover following a burn. The significant reduction of the shrub layer during a burn 280 which we predicted, was not observed in thinning, suggesting the two treatments may not be surrogates 281 in the short-term. However, thinning treatments that include removal of shrub layer are not well 282 represented in these studies so it is possible an overstory thin combined with mechanical shrub removal 283 would mimic the effects of a burn on the shrub stratum. This requires further investigation.

284 There was also an interesting regional effect of treatments; at eastern sites, burning treatments increased total species richness relative to controls and thinning treatments decreased cover relative to controls.

286 This second result is likely a consequence of regional differences in treatments: thinning treatments in 
287 the southeast often explicitly remove the shrub understory whereas, this is not a consistent feature of 288 thinning treatments elsewhere (Schwilk et al 2009). One possible explanation for the regional burn 289 result is that the more mesic and productive eastern sites have faster growth dynamics and therefore, 290 understory herbaceous species respond more quickly to a burn than at western sites. Western sites may 291 exhibit similar responses in longer-term datasets currently not available in the literature.

292 Increase of non-native species due to disturbance is well established (Bartuszevige and Kennedy 2009, 293 Schwilk et al. 2009, Vilà and Ibáñez 2011, Abella and Springer 2015) and this analysis suggests 294 thinning has a greater probability of creating conditions for non-native plants than burns in the short295 term. The mechanism of this differential response is not clear and should be the subject of future 296 investigation. Response of non-native plants to disturbance is likely a complex function of: 1) the plant's 297 functional traits, 2) event-dependent factors such as seasonal timing or severity/intensity, 3) inter298 disturbance intervals that affect length of recovery time between disturbances for sequestering resources 299 or accumulating seed banks, and 4) environmental filters such as site climatic and edaphic conditions 300 (Keeley et al 2005; Havill et al. 2015; Keeley 2015). There is insufficient information in the scientific 301 literature to evaluate effects of disturbance intensity/severity, inter-disturbance intervals, site 302 microclimate, and edaphic conditions on forest understories subjected to management treatments.

303 One concern of manipulating systems for conservation outcomes (e.g., fire surrogate treatments) is the 304 risk of favoring non-native species. The increases in non-native species reported could be biologically 305 significant if allowed to increase in forest understory or if taxa were introduced by the treatment 306 application. However, some forest stands may be at greater risk for establishment of non-native species. 307 For example, non-native species are less likely to establish in the interior of forests, and more likely to 308 establish in areas near other large invasions, fragmented landscapes, and human establishments 309 (Bartuszevige et al. 2006, Vilà and Ibáñez 2011, Johnson et al. 2016). Thus, an important consideration 310 for treatment application is proximity to the wildland urban interface (WUI).

311 To prevent spread of non-native plants into forest ecosystems after treatment, managers should consider 312 several management options including: no treatment, pre-treatment of exotic plants to reduce their 313 abundance prior to treatment, seeding with native plants (Korb et al. 2004), reducing grazing by 314 domestic livestock prior to and immediately after treatment (Keeley 2006), or conducting a low impact 
315 disturbance (e.g. thinning alone, burning alone, or incremental treatments as opposed to both thinning 316 and burning, or conducting the treatments all at once) (Dodson and Fiedler 2006, Laughlin et al. 2008).

317 Thinning treatments in particular can be modified to reduce soil disturbance (which facilitates invasion 318 of non-native plants). Also, thinning in winter months when equipment will drive over snow will also 319 minimize soil disturbance and thus, probability of invasion (Gundale et al. 2005).

320 The goal of returning forest understory composition to its range of historic variability may not always be 321 feasible post-disturbance. Thus, to help guide the choice of management options we encourage 322 managers to use current decision-making frameworks prior to designing an intervention to control non323 native plants post-disturbance. For example, Hobbs et al. (2014) present a decision framework, derived 324 from recent research on novel ecosystems (Hobbs et al. 2009; Hulvey et al. 2013) which helps to 325 identify relative values of ecosystems in different conditions and the management options available in 326 each case. As seen from a landscape perspective, this framework provides a comprehensive approach to 327 decision-making and management, including much-needed prioritization of resource allocations. 328 Numerous alternative decision support approaches are also available (reviewed in Perring et al. 2015).

329 In conclusion, burning and thinning effects on understory plant species richness and cover were either 330 minor or highly variable. These disturbances, particularly thinning, increases non-native species which 331 is likely causing any increases in reported understory richness. It is important to understand the potential 332 threat of these species to native understory species in forested landscapes which is beyond the scope of 333 this study. Also, managers need to recognize that burns can reduce shrub cover which can take longer to 334 recover than herbaceous plants. If these shrubs provide important wildlife habitat or the shrubs are 335 species of conservation concern, thinning might be a better alternative for fuel reduction or forest 336 restoration. We conclude that prescribed fire and thinning treatments can be used successfully to restore 337 understory species richness and cover, but they can create different conditions and these potentially 338 different outcomes need to be considered in the planning of a fuels reduction treatment.

339 There is now a wide literature on the effects of thinning and prescribed fire. Given the diversity of forest 340 types represented and the enormous variation in treatments across studies, we expect very high study-to341 study variation in these ecological responses and, therefore, generalization requires a large number of 342 studies (Verheyen et al. 2016). Yet inconsistent reporting of results hindered our ability to include 
343 studies in this analysis. Abella and Springer (2015) also point this out in their qualitative review. We 344 excluded over a dozen papers that lacked any reporting of variance. Others were excluded because the 345 data reported were summarized in a way that was incompatible with the majority of studies (e.g., only 346 pre or only post treatment differences reported [and therefore, differences between pre and post could 347 not be calculated]). There is growing attention to the value of shared data (Tenopir et al. 2011).

348 Although shared publicly available data is an important goal, traditional meta-analysis is possible using 349 only published summary statistics. For generalization in forest ecology, reporting treatment means and 350 measures of variance is a minimum that editors and reviewers should insist upon.

\section{$351 \quad$ 5. Acknowledgments}

352 This paper was based on a report by Bartuszevige and Kennedy (2009). We thank the USDA/DOI Joint 353 Fire Science Program for funding the original report. We would also like to thank a number of people 354 who participated in the development of Bartuszevige and Kennedy (2009) and thus, contributed to this 355 paper. We thank John Cissel, Colette Coiner, Tim Swedberg, Kim McKague and Becky Jenison for 356 administrative support. Jim Gallagher, Robert Means, Kenneth Outcalt, Dana Perkins, Roger 357 Rosentreter, and Steve Sutherland contributed to the report design and John Bailey, Carl Fiedler, Joe 358 Fontaine, David Hibbs, Dana Perkins and two anonymous referees provided excellent reviews.

\section{References}

360 Abella, S. R., and J. D. Springer. 2015. Effects of tree cutting and fire on understory vegetation in mixed 361 conifer forests. Forest Ecology and Management 335:281-299.

362 Agee, J., and C. Skinner. 2005. Basic principles of forest fuel reduction treatments. Forest Ecology and 363 Management 211:83-96.

364 Aldrich, S. R., C. W. Lafon, H. D. Grissino-Mayer, G. G. DeWeese, and J. A. Hoss. 2010. Three 365 centuries of fire in montane pine-oak stands on a temperate forest landscape. Applied Vegetation 366 Science 13:36-46. 
Bartuszevige, A. M., D. L. Gorchov, and L. Raab. 2006. The relative importance of landscape and 368 community features in the invasion of an exotic shrub in a fragmented landscape. Ecography 29:213369222.

370 Bartuszevige, A., and P. L. Kennedy. 2009. Synthesis of knowledge on the effects of fire and thinning 371 treatments on understory vegetation in US dry forests. Special Report 1095. Oregon State Agricultural 372 Experiment Station; Oregon State University, Agricultural Experiment Station, Corvallis, OR, USA. 373 Boerner, R. E., T. Waldrop, and V. Shelburne. 2006. Wildfire mitigation strategies affect soil enzyme 374 activity and soil organic carbon in loblolly pine (Pinus taeda) forests. Canadian Journal of Forest 375 Research 36:3148-3154.

376 Bond, M. L., R. B. Siegel, R. L. Hutto, V. A. Saab, and S. A. Shunk. 2012. A new forest fire paradigm: 377 the need for high-severity fires. The Wildlife Professional 2012:46-49.

378 Bond, W. J., and B. W. van Wilgen. 1996. Fire and plants. Chapman \& Hall, London, UK.

379 Cochran W.G. 1954. The combination of estimates from different experiments. Biometrics.10: 101-29.

380 Collins, B. M., J. J. Moghaddas, and S. L. Stephens. 2007. Initial changes in forest structure and 381 understory plant communities following fuel reduction activities in a Sierra Nevada mixed conifer 382 forest. Forest Ecology and Management 239:102-111.

383 Crow, T. R., and A. H. Perera. 2004. Emulating natural landscape disturbance in forest management-an 384 introduction. Landscape Ecology 19:231-233.

385 Cyr, D., S. Gauthier, Y. Bergeron, and C. Carcaillet. 2009. Forest management is driving the eastern 386 North American boreal forest outside its natural range of variability. Frontiers in Ecology and the 387 Environment 7:519-524.

388 DeLuca, T., M. MacKenzie, M. Gundale, and W. Holben. 2006. Wildfire-produced charcoal directly 389 influences nitrogen cycling in ponderosa pine forests. Soil Science Society of America Journal 70:448390453.

391 Dodson, E. K. 2004. Monitoring change in exotic plant abundance after fuel reduction/restoration 392 treatments in ponderosa pine forests of western Montana. Dissertation. University of Montana, 393 Missoula, MT, USA. 
394 Dodson, E., and C. Fiedler. 2006. Impacts of restoration treatments on alien plant invasion in Pinus 395 ponderosa forests, Montana, USA. Journal of Applied Ecology 43:887-897.

396 Dodson, E. K., K. L. Metlen, and C. E. Fiedler. 2007. Common and uncommon understory species 397 differentially respond to restoration treatments in ponderosa pine/Douglas-fir forests, Montana. 398 Restoration Ecology 15:696-708.

399 Fontaine, J. B., and P. L. Kennedy. 2012. Avian and small mammal response to fire severity and fire 400 surrogate treatments in U.S. fire-prone forests: a meta-analysis. Ecological Applications 22:1547-1561.

401 Fornwalt, P. J., and M. R. Kaufmann. 2014. Understorey plant community dynamics following a large, 402 mixed severity wildfire in a Pinus ponderosa-Pseudotsuga menziesii forest, Colorado, USA. Journal of 403 Vegetation Science 25:805-818.

404 Fornwalt, P. J., M. R. Kaufmann, and T. J. Stohlgren. 2010. Impacts of mixed severity wildfire on exotic 405 plants in a Colorado ponderosa pine-Douglas-fir forest. Biological Invasions 12:2683-2695.

406 Fulé, P.Z., J. E. Crouseb, J. P. Roccaforteb, and E.L. Kaliesb. 2012. Do thinning and/or burning 407 treatments in western USA ponderosa or Jeffrey pine-dominated forests help restore natural fire 408 behavior? Forest Ecology and Management 269: 68 -81.

409 Fulé, P. Z., D. C. Laughlin, and W. W. Covington. 2005. Pine-oak forest dynamics five years after 410 ecological restoration treatments, Arizona, USA. Forest Ecology and Management 218:129-145.

411 Gilliam, F. S. 2007. The ecological significance of the herbaceous layer in temperate forest ecosystems. 412 BioScience 57:845-858.

413 Gundale, M. J., T. H. DeLuca, C. E. Fiedler, P. W. Ramsey, M. G. Harrington, and J. E. Gannon. 2005. 414 Restoration treatments in a Montana ponderosa pine forest: effects on soil physical, chemical and 415 biological properties. Forest Ecology and Management 213:25-38.

416 Gundale, M. J., K. L. Metlen, C. E. Fiedler, and T. H. DeLuca. 2006. Nitrogen spatial heterogeneity 417 influences diversity following restoration in a ponderosa pine forest, Montana. Ecological Applications $418 \quad 16: 479-489$. 
419 Gurevitch, J., and L. Hedges. 2001. Meta-analysis: combining the results of independent experiments.

420 Pages 378-398 in S. M. Scheiner and J. Gurevitch, editors. Design and analysis of ecological

421 experiments. 2nd editions. Oxford University Press, New York, USA.

422 Havill, S., S. Schwinning, and K. G. Lyons. 2015. Fire effects on invasive and native warm-season grass

423 species in a North American grassland at a time of extreme drought. Applied Vegetation Science 424 18:637-649.

425 Hobbs, R. J., Higgs, E., and J. A. Harris. 2009. Novel ecosystems: implications for conservation and 426 restoration. Trends in Ecology and Evolution 24: 599-605.

427 Hobbs, R. J., E. S. Higgs, C. M. Hall, P. Bridgewater, F. S. Chapin III, E. C. Ellis, J. J. Ewel, L. M. 428 Hallett, J. A. Harris, K. B. Hulvey, S. T. Jackson, P. L. Kennedy, C. Kueffer, L. Lach, T. C. Lantz, A. E. 429 Lugo, J. Mascaro, S. D. Murphy, C. R. Nelson, M. P. Perring, D. M. Richardson, T. R. Seastadt, R. J. 430 Standish, B. M. Starzomski, K. N. Suding, P. M. Tognetti, L. Yakob, and L. Yung. 2014. Managing the 431 whole landscape: historical, hybrid and novel ecosystems. Frontiers in Ecology and the Environment $432 \quad 12: 557-564$.

433 Huffman, D., M. Stoddard, J. Springer, J. Crouse, and W. Chancellor. 2013. Understory plant 434 community responses to hazardous fuels reduction treatments in pinyon-juniper woodlands of Arizona, 435 USA. Forest Ecology and Management 289:478-488.

436 Hulvey, K. B., R. J. Standish, L. M. Hallett, B. M. Starzomski, S. D. Murphy, C. R. Nelson, M. R. 437 Gardner, P. L. Kennedy, T. Seastadt and K. N. Suding. 2013. Incorporating novel ecosystems into 438 management frameworks. Pages 157-171 In R. J. Hobbs, E. Higgs, and C. Hall (Eds). Novel Ecosystems. 439 Intervening in the new ecological world order. Wiley-Blackwell, West Sussex, UK.

440 Johnson, S. E., K. L. Amatangelo, P. A. Townsend and D. M. Waller. 2016. Large, connected floodplain 441 forests prone to flooding best sustain plant diversity. Ecology 97:3019-3030.

442 Kane, J. M., J. M. Varner, E. E. Knapp, and R. F. Powers. 2010. Understory vegetation response to 443 mechanical mastication and other fuels treatments in a ponderosa pine forest. Applied Vegetation 444 Science 13:207-220. 
445 Keeley, J. E. 2006. Fire management impacts on invasive plants in the western United States.

446 Conservation Biology 20:375-384.

447 Keeley, J. E. 2015. Attacking invasive grasses. Applied Vegetation Science 18: 541-542.

448 Keeley, J. E., C. J. Fotheringham, and M. Baer-Keeley. 2005. Determinants of postfire recovery and 449 succession in Mediterranean-climate shrublands of California. Ecological Applications 15: 1515-1534.

450 Kerns, B. K., W. G. Thies, and C. G. Niwa. 2006. Season and severity of prescribed burn in ponderosa 451 pine forests: implications for understory native and exotic plants. Ecoscience 13:44-55.

452 Kreye, J. K and L. N. Kobziar. 2015. The effect of mastication on surface fire behaviour, fuels 453 consumption and tree mortality in pine flatwoods of Florida, USA. International Journal of Wildland 454 Fire 24: 573-579.

455 Knapp, E. E., D. W. Schwilk, J. M. Kane, and J. E. Keeley. 2006. Role of burning season on initial 456 understory vegetation response to prescribed fire in a mixed conifer forest. Canadian Journal of Forest 457 Research 37:11-22.

458 Korb, J. E., N. C. Johnson, and W. Covington. 2004. Slash pile-burning effects on soil biotic and 459 chemical properties and plant establishment: recommendations for amelioration. Restoration Ecology $460 \quad 12: 52-62$.

461 Laughlin, D. C., J. D. Bakker, M. L. Daniels, M. M. Moore, C. A. Casey, and J. D. Springer. 2008. 462 Restoring plant species diversity and community composition in a ponderosa pine-bunchgrass 463 ecosystem. Plant Ecology 197:139-151.

464 Mason, G. J., T. T. Baker, D. S. Cram, J. C. Boren, A. G. Fernald, and D. M. VanLeeuwen. 2009. 465 Mechanical fuel treatment effects on vegetation in a New Mexico dry mixed conifer forest. Forest 466 Ecology and Management 257:868-875.

467 McIver, J. D., S. L. Stephens, J. K. Agee, J. Barbour, R. E. Boerner, C. B. Edminster, K. L. Erickson, K. 468 L. Farris, C. J. Fettig, C. E. Fiedler, and others. 2013. Ecological effects of alternative fuel-reduction 469 treatments: highlights of the National Fire and Fire Surrogate study (FFS). International Journal of 470 Wildland Fire 22:63-82. 
471 Metlen, K. L., and C. E. Fiedler. 2006. Restoration treatment effects on the understory of ponderosa 472 pine/Douglas-fir forests in western Montana, USA. Forest Ecology and Management 222:355-369. 473 Moghaddas, J. J., R. A. York, and S. L. Stephens. 2008. Initial response of conifer and California black 474 oak seedlings following fuel reduction activities in a Sierra Nevada mixed conifer forest. Forest Ecology 475 and Management 255:3141-3150.

476 Murtaugh, P. A. 2002. Journal quality, effect size, and publication bias in meta-analysis. Ecology $477 \quad 83: 1162-1166$.

478 Nelson, C. R., C. B. Halpern, and J. K. Agee. 2008. Thinning and burning result in low-level invasion 479 by nonnative plants but neutral effects on natives. Ecological Applications 18:762-770.

480 O’Connor, C., R. Miller, and J. D. Bates. 2013. Vegetation response to western juniper slash treatments. 481 Environmental Management 52:553-566.

482 Odion, D. C., C. T. Hanson, A. Arsenault, W. L. Baker, D. A. DellaSala, R. L. Hutto, W. Klenner, M. A. 483 Moritz, R. L. Sherriff, T. T. Veblen, and others. 2014. Examining historical and current mixed-severity 484 fire regimes in ponderosa pine and mixed-conifer forests of western North America. PloS One 9:e87852. 485 Perring, M. P., R. J. Standish, J. N. Price, M. D. Craig, T. E. Erickson, K. X. Ruthrof, A. S. Whiteley, L. 486 E. Valentine, and R. J. Hobbs. 2015. Advances in restoration ecology: rising to the challenges of the 487 coming decades. Ecosphere 6:1-25.

488 Phillips, R., and T. Waldrop. 2008. Changes in vegetation structure and composition in response to fuel 489 reduction treatments in the South Carolina Piedmont. Forest Ecology and Management 255:3107-3116.

490 Phillips, R., Hutchinson, T., Brudnak, L., Waldrop, T., 2007. Fire and fire surrogate treatments in 491 mixed-oak forests: effects on herbaceous layer vegetation. In: Butler, B.W., Cook, W., comps. The Fire 492 Environment-Innovations, Management, and Policy; Conference Proceedings. 26-30th March 2007; 493 Destin, FL. Proceedings RMRS-P-46. Fort Collins, CO, USA.

494 Provencher, L., and J. Thompson. 2014. Vegetation responses to pinyon-juniper treatments in eastern 495 Nevada. Rangeland Ecology and Management 67:195-205.

496 Pyke, D.A., M. L. Brooks, and C. D’Antonio. 2010. Fire as a restoration tool: a decision framework for 497 predicting the control or enhancement of plants using fire. Restoration Ecology 18: 274-284. 
498 R Development Core Team. 2013. R: A language and environment for statistical computing. R

499 Foundation for Statistical Computing, Vienna, Austria.

500 Schoennagel, T., and C. R. Nelson. 2011. Restoration relevance of recent National Fire Plan treatments

501 in forests of the western United States. Frontiers in Ecology and the Environment 9:271-277.

502 Schoennagel, T., T. Veblen, and W. Romme. 2004. The interaction of fire, fuels, and climate across

503 Rocky Mountain forests. BioScience 54:661-676.

504 Schwilk, D., J. Keeley, E. Knapp, J. McIver, J. Bailey, C. Fettig, C. Fiedler, R. Harrod, J. Moghaddas, 505 K. Outcalt, and others. 2009. The national Fire and Fire Surrogate study: effects of fuel reduction 506 methods on forest vegetation structure and fuels. Ecological Applications 19:285-304.

507 Spetich, M. A., R. W. Perry, C. A. Harper, and S. L. Clark. 2011. Fire in eastern hardwood forests 508 through 14,000 years. Pages 41-58 in Sustaining Young Forest Communities. Springer, Netherlands.

509 Stephens, S. L., J. D. McIver, R. E. J. Boerner, C. J. Fettig, J. B. Fontaine, B. R. Hartsough, P. L. 510 Kennedy, and D. W. Schwilk. 2012. Effects of forest fuel reduction treatments in the United States. 511 BioScience 62:549-560.

512 Sterne, J. A. C., and Egger, M. 2001. Funnel plots for detecting bias in meta-analysis: guidelines on 513 choice of axis. Journal of Clinical Epidemiology 54: 1046-1055.

514 Tenopir, C., S. Allard, K. Douglass, A. U. Aydinoglu, L. Wu, E. Read, M. Manoff, and M. Frame. Data 515 sharing by scientists: practices and perceptions. PLoS One 6(6): e21101.

516 doi:10.1371/journal.pone.0021101

517 van Mantgem, P. J, N. L. Stephenson, E. Knapp, J. Battles, and J. E. Keeley. 2011. Long-term effects of 518 prescribed fire on mixed conifer forest structure in the Sierra Nevada, California. Forest Ecology and 519 Management 261: 989 - 994.

520 Verheyen, K., D. F. Pieter, L. Baeten, D. M. Waller, R. Hedl, M. P. Perring, H. Blondeel, J. Brunet, M. 521 Chudomelova and G. Decocq. 2016. Combining biodiversity resurveys across regions to advance global 522 change research. BioScience 67:73-83.

523 Viechtbauer, W. 2010. Conducting meta-analyses in R with the metafor package. Journal of Statistical 524 Software 36:1-48. 
Vilà, M. and I. Ibáñez. 2011. Plant invasions in the landscape. Landscape Ecology 26:461-472.

526 Waldrop, T. A., D. A. Yaussy, R. J. Phillips, T. A. Hutchinson, L. Brudnak, and R. E. Boerner. 2008.

527 Fuel reduction treatments affect stand structure of hardwood forests in western North Carolina and

528 southern Ohio, USA. Forest Ecology and Management 255:3117-3129.

529 Waldrop, T., R. A. Phillips, and D. A. Simon. 2010. Fuels and predicted fire behavior in the southern

530 Appalachian Mountains after fire and fire surrogate treatments. Forest Science 56:32-45.

531 Weekley, C. W., E. S. Menges, A. L. Craddock, and R. Yahr. 2013. Logging as a pretreatment or 532 surrogate for fire in restoring Florida scrub. Castanea 78:15-27.

533 Wienk, C. L., C. H. Sieg, and G. R. McPherson. 2004. Evaluating the role of cutting treatments, fire and 534 soil seed banks in an experimental framework in ponderosa pine forests of the Black Hills, South 535 Dakota. Forest Ecology and Management 192:375-393.

536 Wolk, B., and M. E. Rocca. 2009. Thinning and chipping small-diameter ponderosa pine changes 537 understory plant communities on the Colorado Front Range. Forest Ecology and Management 257:8553895.

539 Youngblood, A., K. L. Metlen, and K. Coe. 2006. Changes in stand structure and composition after 540 restoration treatments in low elevation dry forests of northeastern Oregon. Forest Ecology and 541 Management 234:143-163.

542 Zald, H. S., A. N. Gray, M. North, and R. A. Kern. 2008. Initial tree regeneration responses to fire and 543 thinning treatments in a Sierra Nevada mixed-conifer forest, USA. Forest Ecology and Management $544 \quad 256: 168-179$.

545 Zhang, J., M. W. Ritchie, and W. W. Oliver. 2008a. Vegetation responses to stand structure and 546 prescribed fire in an interior ponderosa pine ecosystem this article is one of a selection of papers from 547 the Special Forum on Ecological Studies in Interior Ponderosa Pine — First Findings from Blacks 548 Mountain Interdisciplinary Research. Canadian Journal of Forest Research 38:909-918.

549 Zhang, J., J. Webster, R. F. Powers, and J. Mills. 2008b. Reforestation after the Fountain Fire in 550 northern California: an untold success story. Journal of Forestry 106:425-430. 
551 Zouhar, K., J. K. Smith, S. Sutherland, M. L. Brooks, and others. 2008. Wildland fire in ecosystems: fire 552 and nonnative invasive plants. General Technical Report RMRS-GTR-42-vol. 6. Department of 553 Agriculture, Forest Service, Rocky Mountain Research Station. Ogden, UT, USA. 355 p. 
Tables

Table 1. Papers with data included in this study. Some papers reported data from multiple sites (e.g., Waldrop et al 2008) or from multiple treatments. These are distinguished by abbreviations in parentheses.

\begin{tabular}{|c|c|c|c|c|c|c|}
\hline Paper & Location & Measurements & Thinning Methodology & $\begin{array}{c}\text { Fire } \\
\text { Intensity }\end{array}$ & Forest Type & \begin{tabular}{|c|} 
Years Since \\
Treatment \\
\end{tabular} \\
\hline Collins et al 2007 & $\begin{array}{l}\text { Blodgett Forest } \\
\text { Research Station, } \\
\text { California }\end{array}$ & $\begin{array}{c}\text { Herbaceous Cover } \\
\text { Shrub Cover } \\
\text { Total Cover } \\
\text { Total Richness } \\
\text { Exotic Cover } \\
\text { Exotic Richness }\end{array}$ & $\begin{array}{l}\text { Thinning from below and } \\
\text { rotary mastication }\end{array}$ & Medium & Mixed conifer & 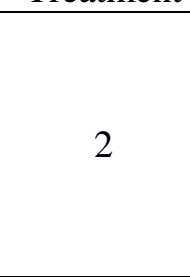 \\
\hline Dodson et al 2007 & $\begin{array}{c}\text { Lubrecht } \\
\text { Experimental } \\
\text { Forest, Montana }\end{array}$ & $\begin{array}{l}\text { Total Richness } \\
\text { Exotic Cover }\end{array}$ & $\begin{array}{l}\text { Improvement/selection } \\
\text { cutting and low thinning }\end{array}$ & Low & Ponderosa pine/Douglas Fir & 3.5 \\
\hline Dodson 2004 & $\begin{array}{c}\text { Lubrecht } \\
\text { Experimental } \\
\text { Forest, Montana }\end{array}$ & Exotic Richness & NA & Low & Ponderosa pine & 2.5 \\
\hline $\begin{array}{c}\text { Fornwalt et al } \\
2010(\mathrm{RL})\end{array}$ & \begin{tabular}{|c|} 
Pike National \\
Forest, Colorado \\
\end{tabular} & Total Cover & NA & Low & Ponderosa pine/Douglas fir & 2 \\
\hline $\begin{array}{c}\text { Fornwalt et al } \\
2010(\mathrm{UH})\end{array}$ & $\begin{array}{c}\text { Pike National } \\
\text { Forest, Colorado }\end{array}$ & Total Cover & NA & High & Ponderosa pine/Douglas fir & 2 \\
\hline $\begin{array}{l}\text { Fornwalt et al } \\
2010 \text { (UL) }\end{array}$ & $\begin{array}{c}\text { Pike National } \\
\text { Forest, Colorado }\end{array}$ & $\begin{array}{c}\text { Total Cover } \\
\text { Exotic Cover } \\
\text { Exotic Richness }\end{array}$ & NA & Low & Ponderosa pine/Douglas fir & 2 \\
\hline $\begin{array}{l}\text { Fornwalt et al } \\
2010(\text { UM) }\end{array}$ & \begin{tabular}{|c|} 
Pike National \\
Forest, Colorado \\
\end{tabular} & Total Cover & NA & Medium & Ponderosa pine/Douglas fir & 2 \\
\hline $\begin{array}{l}\text { Fornwalt et al } \\
2014(\mathrm{R})\end{array}$ & $\begin{array}{c}\text { Pike National } \\
\text { Forest, Colorado }\end{array}$ & $\begin{array}{c}\text { Herbaceous Cover } \\
\text { Herbaceous Richness }\end{array}$ & NA & Low & Ponderosa pine/Douglas fir & 2 \\
\hline $\begin{array}{l}\text { Fornwalt et al } \\
2014(\mathrm{U})\end{array}$ & $\begin{array}{c}\text { Pike National } \\
\text { Forest, Colorado }\end{array}$ & $\begin{array}{c}\text { Herbaceous Cover } \\
\text { Herbaceous Richness } \\
\text { Total Cover } \\
\text { Total Richness } \\
\end{array}$ & NA & Medium & Ponderosa pine/Douglas fir & 2 \\
\hline Fulé et al 2005 & $\begin{array}{l}\text { Kaibab National } \\
\text { Forest, Arizona }\end{array}$ & $\begin{array}{c}\text { Total Cover } \\
\text { Total Richness }\end{array}$ & NA & Low & Pine-oak & 4 \\
\hline $\begin{array}{c}\text { Huffman et al } \\
2013\end{array}$ & $\begin{array}{c}\text { Kaibab NF, } \\
\text { Arizona }\end{array}$ & $\begin{array}{c}\text { Herbaceous Cover } \\
\text { Herbaceous Richness }\end{array}$ & Thinning from below & Low & Pinyon - juniper & 5 \\
\hline
\end{tabular}




\begin{tabular}{|c|c|c|c|c|c|c|}
\hline & & $\begin{array}{c}\text { Shrub Cover } \\
\text { Shrub Richness } \\
\text { Total Cover } \\
\text { Total Richness } \\
\text { Exotic Richness } \\
\end{array}$ & & & & \\
\hline Kane et al 2010 & $\begin{array}{c}\text { Challenge } \\
\text { Experimental } \\
\text { Forest, California }\end{array}$ & $\begin{array}{c}\text { Herbaceous Richness } \\
\text { Shrub Richness } \\
\text { Total Richness } \\
\text { Exotic Richness } \\
\end{array}$ & $\begin{array}{l}\text { Mastication using a rotary } \\
\text { drum style masticating } \\
\text { head with fixed teeth }\end{array}$ & Medium & Ponderosa pine & 4 \\
\hline Kerns et al 2006 & $\begin{array}{c}\text { Malheur NF, } \\
\text { Oregon }\end{array}$ & $\begin{array}{c}\text { Herbaceous Cover } \\
\text { Exotic Cover } \\
\text { Exotic Richness } \\
\end{array}$ & NA & Low & Ponderosa pine & 5 \\
\hline Knapp et al 2006 & $\begin{array}{c}\text { Sequoia National } \\
\text { Park }\end{array}$ & $\begin{array}{c}\text { Herbaceous Cover } \\
\text { Herbaceous Richness } \\
\text { Shrub Cover } \\
\text { Shrub Richness } \\
\text { Total Cover } \\
\text { Total Richness }\end{array}$ & NA & Medium & Mixed conifer & 3 \\
\hline $\begin{array}{l}\text { Laughlin et al } \\
2008\end{array}$ & $\begin{array}{c}\text { Coconino } \\
\text { National Forest, } \\
\text { Arizona } \\
\end{array}$ & Total Richness & $\begin{array}{c}\text { Thinning overstory } \\
\text { vegetation }\end{array}$ & NA & Ponderosa pine & 3 \\
\hline $\begin{array}{c}\text { Mason et al } 2009 \\
\text { (BA) }\end{array}$ & $\begin{array}{c}\text { Lincoln National } \\
\text { Forest, New } \\
\text { Mexico } \\
\end{array}$ & $\begin{array}{c}\text { Herbaceous Cover } \\
\text { Total Cover } \\
\text { Total Richness } \\
\end{array}$ & $\begin{array}{l}\text { Non-commercial thin with } \\
\text { slash scattered }\end{array}$ & NA & Mixed conifer & 1 \\
\hline $\begin{array}{c}\text { Mason et al } 2009 \\
\text { (CO) }\end{array}$ & \begin{tabular}{|c|} 
Lincoln National \\
Forest, New \\
Mexico \\
\end{tabular} & $\begin{array}{c}\text { Herbaceous Cover } \\
\text { Total Cover } \\
\text { Total Richness } \\
\end{array}$ & $\begin{array}{l}\text { Non-commercial thin with } \\
\text { slash scattered }\end{array}$ & NA & Mixed conifer & 2 \\
\hline $\begin{array}{c}\text { Mason et al } 2009 \\
\text { (SL) }\end{array}$ & $\begin{array}{c}\text { Lincoln National } \\
\text { Forest, New } \\
\text { Mexico }\end{array}$ & $\begin{array}{c}\text { Herbaceous Cover } \\
\text { Total Cover } \\
\text { Total Richness }\end{array}$ & $\begin{array}{l}\text { Commercial harvesting } \\
\text { with slash removed }\end{array}$ & NA & Mixed conifer & 2 \\
\hline $\begin{array}{l}\text { Metlen and } \\
\text { Fiedler } 2006\end{array}$ & $\begin{array}{c}\text { Lubrecht } \\
\text { Experimental } \\
\text { Forest, Montana }\end{array}$ & $\begin{array}{c}\text { Herbaceous Richness } \\
\text { Herbaceous Cover } \\
\text { Shrub Cover } \\
\text { Shrub Richness } \\
\text { Total Cover } \\
\text { Total Richness } \\
\text { Exotic Cover } \\
\text { Exotic Richness }\end{array}$ & $\begin{array}{l}\text { Improvement/selection } \\
\text { cutting and low thinning }\end{array}$ & Low & Ponderosa pine/Douglas fir & 2 \\
\hline
\end{tabular}




\begin{tabular}{|c|c|c|c|c|c|c|}
\hline Nelson et al 2008 & $\begin{array}{c}\text { Colville, } \\
\text { Okanogan, } \\
\text { Wenatchee } \\
\text { National Forests, } \\
\text { Washington }\end{array}$ & $\begin{array}{c}\text { Herbaceous Richness } \\
\text { Herbaceous Cover } \\
\text { Shrub Cover } \\
\text { Shrub Richness } \\
\text { Total Cover } \\
\text { Total Richness } \\
\text { Exotic Cover } \\
\text { Exotic Richness }\end{array}$ & $\begin{array}{l}\text { Mechanical removal of } \\
\text { small-diameter trees }\end{array}$ & Low & Ponderosa pine & 8 \\
\hline $\begin{array}{l}\text { O'Connor et al } \\
2013\end{array}$ & $\begin{array}{c}\text { High Desert } \\
\text { Ecological } \\
\text { Province, Oregon }\end{array}$ & Herbaceous Cover & Cut-and-leave & NA & Pinyon - juniper & 2 \\
\hline $\begin{array}{l}\text { Phillips et al } 2007 \\
\qquad(\mathrm{OH})\end{array}$ & $\begin{array}{c}\text { Central } \\
\text { Appalachian } \\
\text { Plateau,Ohio }\end{array}$ & $\begin{array}{l}\text { Herbaceous Richness } \\
\text { Herbaceous Cover } \\
\text { Total Richness }\end{array}$ & $\begin{array}{c}\text { Commercial thinning from } \\
\text { below }\end{array}$ & Medium & Mixed hardwood & 2 \\
\hline $\begin{array}{l}\text { Phillips et al } 2007 \\
\text { (SA) }\end{array}$ & $\begin{array}{c}\text { Southern } \\
\text { Appalachian } \\
\text { Mountains, North } \\
\text { Carolina } \\
\end{array}$ & $\begin{array}{l}\text { Herbaceous Richness } \\
\text { Herbaceous Cover } \\
\text { Total Richness }\end{array}$ & $\begin{array}{l}\text { Chainsaw felling of small, } \\
\text { suppressed trees and shrubs }\end{array}$ & Medium & Mixed hardwood & 2 \\
\hline $\begin{array}{l}\text { Phillips and } \\
\text { Waldrop } 2008\end{array}$ & $\begin{array}{l}\text { Clemson } \\
\text { Experimental } \\
\text { Forest, South } \\
\text { Carolina } \\
\end{array}$ & Total Richness & $\begin{array}{c}\text { Cutting of trees to a } \\
\text { residual tree spacing of } \sim 6 \\
\text { m }\end{array}$ & Medium & Pinus taeda/Pinus echinata & 2 \\
\hline $\begin{array}{l}\text { Provencher and } \\
\text { Thompson } 2014\end{array}$ & $\begin{array}{l}\text { Smith Valley, } \\
\text { Utah }\end{array}$ & $\begin{array}{c}\text { Herbaceous Cover } \\
\text { Shrub Cover }\end{array}$ & Lop and scatter & NA & Pinyon - juniper woodlands & 4 \\
\hline $\begin{array}{l}\text { Waldrop et al } \\
2010\end{array}$ & $\begin{array}{c}\text { Southern } \\
\text { Appalachian } \\
\text { Mountain, North } \\
\text { Carolina } \\
\end{array}$ & Shrub Cover & $\begin{array}{l}\text { Chainsaw felling of small } \\
\text { trees and shrubs }\end{array}$ & Medium & Mixed hardwood & 3 \\
\hline $\begin{array}{l}\text { Waldrop et al } \\
2008 \text { (GR) }\end{array}$ & $\begin{array}{l}\text { Green River, } \\
\text { North Carolina }\end{array}$ & $\begin{array}{l}\text { Herbaceous Cover } \\
\text { Shrub Cover } \\
\text { Total Cover }\end{array}$ & $\begin{array}{c}\text { Chainsaw felling of trees > } \\
1.8 \mathrm{~m} \text { tall and all mountain } \\
\text { laurel and rhododendron } \\
\text { stems }\end{array}$ & Medium & Mixed hardwood & 2 \\
\hline $\begin{array}{l}\text { Waldrop et al } \\
2008(\mathrm{OH})\end{array}$ & Ohio Hills, Ohio & $\begin{array}{c}\text { Herbaceous Cover } \\
\text { Shrub Cover } \\
\text { Total Cover } \\
\end{array}$ & $\begin{array}{c}\text { Commercial thinning from } \\
\text { below }\end{array}$ & Medium & Mixed hardwood & 2 \\
\hline $\begin{array}{l}\text { Weekley et al } \\
2013\end{array}$ & $\begin{array}{l}\text { Lake Wales } \\
\text { Ridge State } \\
\text { Forest, Florida }\end{array}$ & Herbaceous Cover & $\begin{array}{l}\text { Logging: harvesting of all } \\
\text { merchantable pine }\end{array}$ & Medium & Longleaf pine & 2 \\
\hline
\end{tabular}




\begin{tabular}{|c|c|c|c|c|c|c|}
\hline Wienk et al 2004 & $\begin{array}{l}\text { Badger Game } \\
\text { Production Area, } \\
\text { South Dakota }\end{array}$ & Total Richness & $\begin{array}{l}\text { Cutting of trees to leave a } \\
\text { basal area of } \sim 12 \mathrm{~m}^{2} / \mathrm{ha}, \\
\text { trees and slash removed }\end{array}$ & Low & Ponderosa pine & 2 \\
\hline $\begin{array}{l}\text { Wolk and Rocca } \\
2009\end{array}$ & $\begin{array}{c}\text { Heil Valley } \\
\text { Ranch, Colorado }\end{array}$ & $\begin{array}{l}\text { Total Richness } \\
\text { Exotic Richness }\end{array}$ & $\begin{array}{l}\text { Chainsaw felling and hand } \\
\text { crew or all-terrain vehicle } \\
\text { skidding }\end{array}$ & NA & Ponderosa pine & 3 \\
\hline $\begin{array}{c}\text { Youngblood et al } \\
2006\end{array}$ & $\begin{array}{l}\text { Blue Mountains, } \\
\text { Oregon }\end{array}$ & Total Richness & $\begin{array}{l}\text { Cut-to-length harvesting } \\
\text { using a single-grip } \\
\text { harvester and forwarder to } \\
\text { remove merchantable live } \\
\text { and standing dead and } \\
\text { down material }\end{array}$ & Low & Ponderosa pine/Douglas fir & 5 \\
\hline Zald et al 2008 & $\begin{array}{c}\text { Teakettle } \\
\text { Experimental } \\
\text { Forest, California }\end{array}$ & Herbaceous Cover & $\begin{array}{l}\text { Removal of trees between } \\
25 \text { and } 76 \mathrm{~cm} \text { diameter at } \\
\text { breast height, while } \\
\text { retaining at least } 40 \% \\
\text { canopy cover }\end{array}$ & Medium & Mixed conifer & 1.5 \\
\hline Zhang et al 2008a & $\begin{array}{l}\text { Blacks Mountain } \\
\text { Experimental } \\
\text { Forest, California }\end{array}$ & $\begin{array}{c}\text { Shrub Cover } \\
\text { Shrub Richness } \\
\text { Total Richness }\end{array}$ & $\begin{array}{l}\text { Mechanical thinning, not } \\
\text { otherwise specified }\end{array}$ & NA & Ponderosa pine & 5 \\
\hline
\end{tabular}


Table 2. Contrast coefficient lower (lb) and upper (ub) confidence limits (90\%) and adjusted $p$ values for pairwise treatment contrasts (15 comparisons tested). Positive coefficients indicate response variable was higher in first treatment listed, negative indicates response was greater in second. We considered all hypotheses as one-tailed and therefore report 90\% confidence intervals. We report experiment-wide adjusted $\mathrm{p}$-values $<0.1$ as significant (in bold).

\begin{tabular}{lllllllllll} 
Response & \multicolumn{3}{l}{ Burn vs Control } & \multicolumn{3}{c}{ Burn vs Thin } & \multicolumn{3}{c}{ Thin vs Control } \\
\hline & $\mathrm{lb}$ & $\mathrm{ub}$ & $\mathrm{adj} . \mathrm{p}$ & $\mathrm{lb}$ & $\mathrm{ub}$ & $\mathrm{adj} . \mathrm{p}$ & $\mathrm{lb}$ & $\mathrm{ub}$ & $\mathrm{adj} . \mathrm{p}$ \\
\cline { 2 - 10 } $\begin{array}{l}\text { exotic } \\
\text { richness }\end{array}$ & 0.240 & 1.05 & $>0.116$ & -0.880 & -0.018 & $>0.1$ & 0.534 & 1.29 & $\mathbf{0 . 0 0 1}$ \\
$\begin{array}{l}\text { herb cover } \\
\text { shrub }\end{array}$ & -0.061 & 0.668 & $>0.1$ & -0.407 & 0.339 & $>0.1$ & -0.002 & 0.672 & $>0.1$ \\
$\begin{array}{l}\text { cover } \\
\text { total cover }\end{array}$ & -1.36 & -0.453 & $\mathbf{0 . 0 1 4}$ & -1.56 & -0.089 & $>0.1$ & -0.384 & 0.728 & $>0.1$ \\
$\begin{array}{l}\text { total } \\
\text { richness }\end{array}$ & -0.624 & -0.031 & $>0.1$ & -2.31 & 0.201 & $>0.1$ & -0.166 & 0.696 & $>0.1$ \\
\end{tabular}


Figure 1: Geographic distribution of data sources; see Table 1 for details of each study. Each circle represents a study site. We searched literature from North American forests that historically experienced frequent surface fire regimes ( $<20$ years fire return interval). After vetting, only studies located in the USA remained.

Figure 2: Forest plot indicating standardized effect sizes (squares), standard deviations (error bars), and $95 \%$ confidence intervals of effect sizes for exotic species richness thinning vs control contrasts across relevant studies. The black polygon in the final row ("RE Model") indicates estimated average effect size with the horizontal extent of the polygon indicating the $95 \% \alpha=0.1$ confidence intervals of that estimate. Numbers on right of plot give these standardized effect sizes and upper and lower confidence intervals. Thinning treatments caused an increase in exotic species richness compared with control treatments (adjusted $p=0.001$ ). Studies are listed on the left, see Table 1.

Figure 3: Burn vs Control effect sizes for total species richness (Hedge's g, Gurevitch and Hedges 2001). Mean effect sizes and $95 \%$ confidence intervals are shown for each study. Burning had a variable effect on total species richness with increases relative to controls at eastern, but not western sites (no main effect, latitude significant modifier, adjusted $\mathrm{p}=0.019, \mathrm{~N}=12$ ).

Figure 4: Forest plot indicating standardized effect sizes (squares), standard deviations (error bars), and $95 \%$ confidence intervals of effect sizes for shrub cover burning vs control contrasts. Waldrop et al (2008) report data from two sites and these were treated separately in our analyses $(\mathrm{OH}=\mathrm{Ohio}$ site, GR $=$ North Carolina site Table 1). The black polygon in the final row ("RE Model") indicates estimated average effect size with the horizontal extent of the polygon indicating the $95 \% \alpha=0.1$ confidence intervals of that estimate. Numbers on right of plot give these standardized effect sizes and upper and lower confidence intervals. Burning treatments caused a decrease in shrub cover when compared with control treatments (adjusted $\mathrm{p}=0.014$ ). Studies are listed on the left, see Table 1.

Figure 5: Thin vs Control effect sizes for total understory cover (Hedge's g, Gurevitch and Hedges 2001). Mean effect sizes and confidence intervals are shown for each study. Burning had a variable effect on total species richness with increases relative to controls at eastern, but not western sites (no main effect, latitude significant modifier, adjusted $\mathrm{p}=0.002, \mathrm{~N}=2015$ ). 


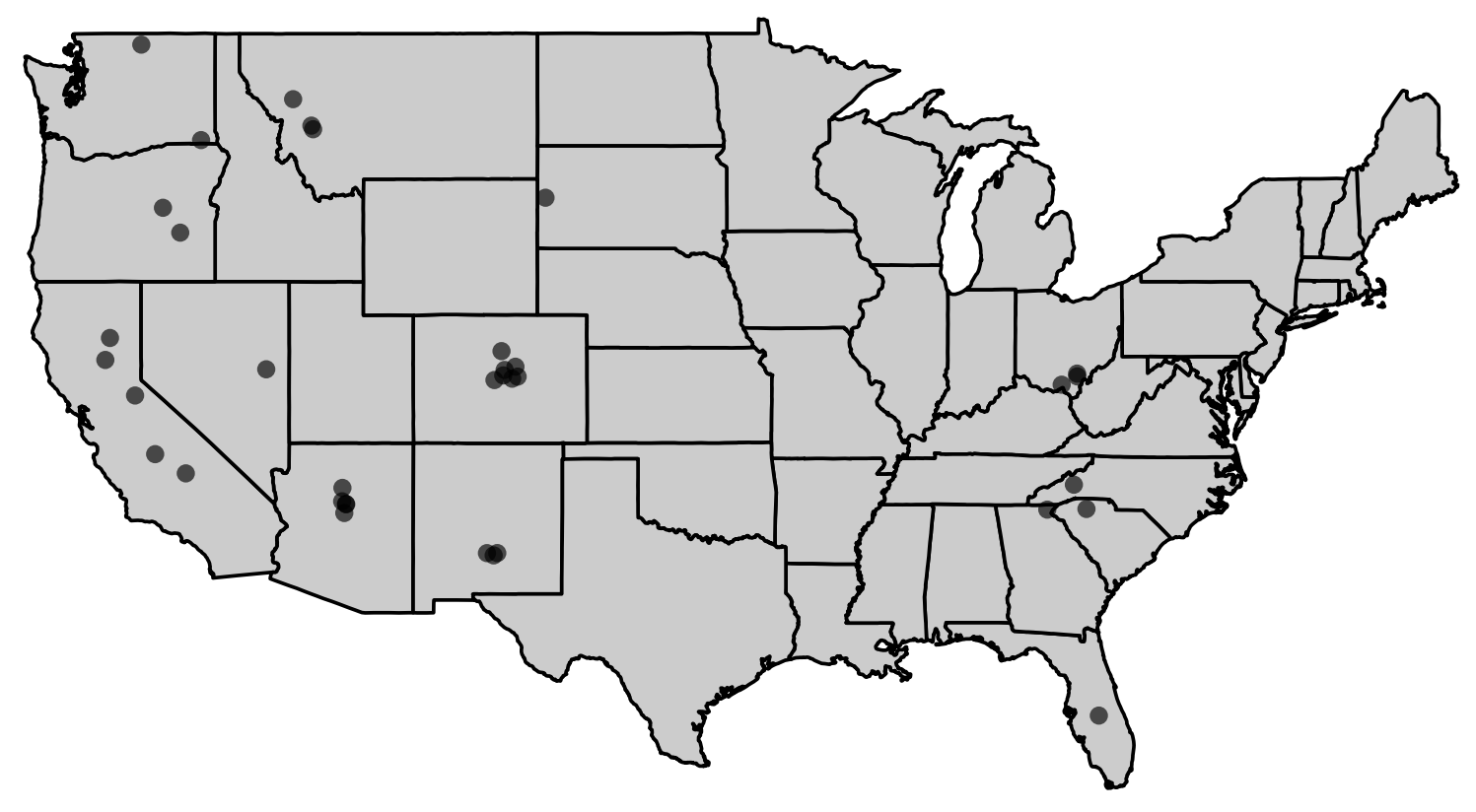


Collins et al 2007

Dodson 2004

Huffman et al 2013

Kane et al 2010

Metlen and Fiedler 2006

Nelson et al 2008

Wolk and Rocca 2009

RE Model
$1.47[-0.05,2.98]$

$0.54[-0.14,1.22]$

$1.10[0.38,1.83]$

$1.35[0.06,2.63]$

$1.25[-0.22,2.72]$

$2.15[1.45,2.86]$

$0.75[-0.09,1.58]$

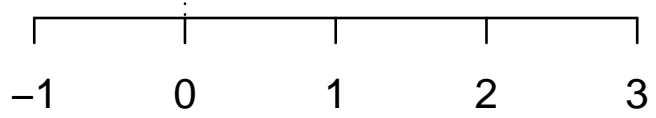

Standardized Mean Difference 


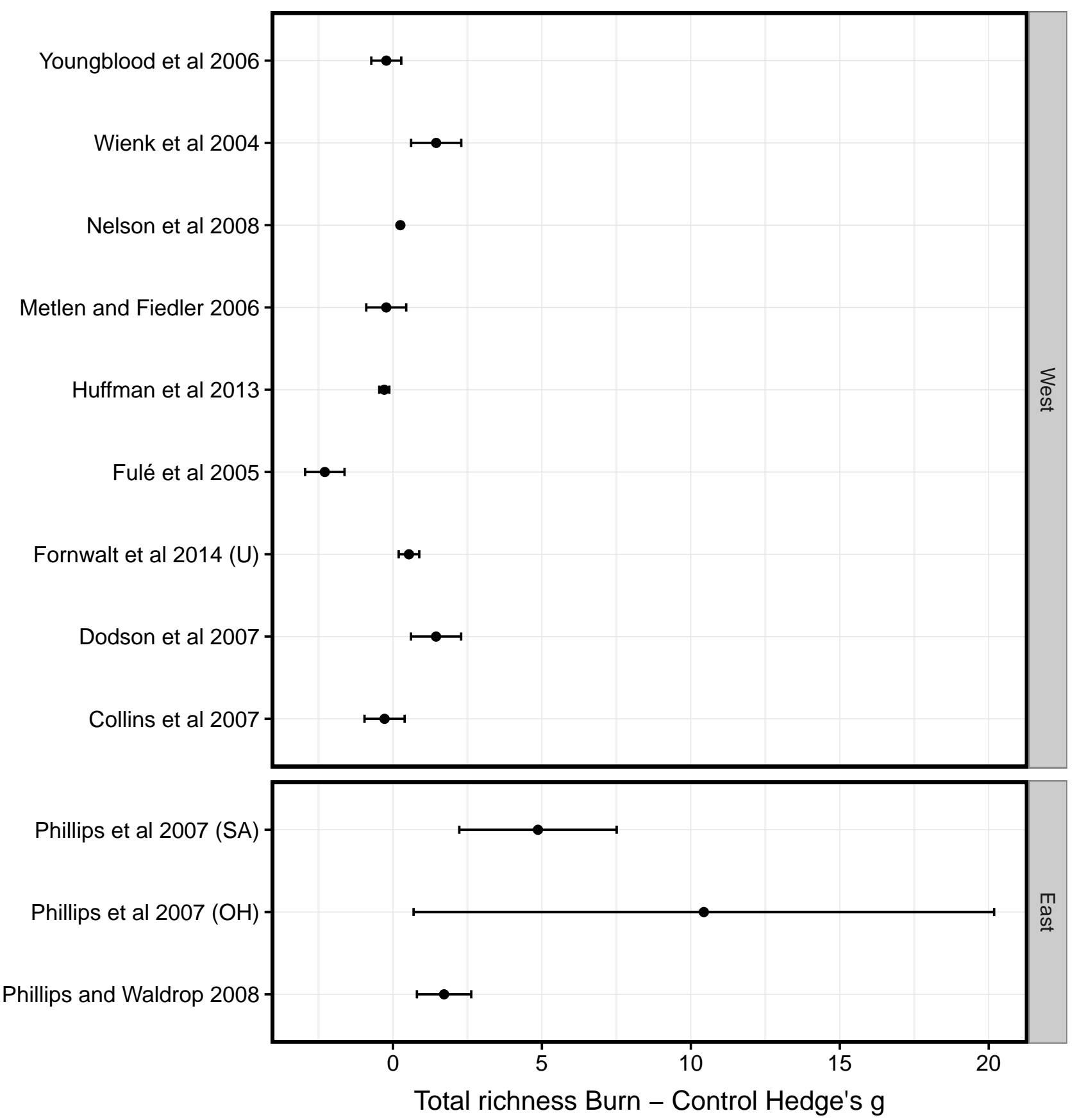


Author(s) and Year

Shrub cover, Burn - Control [95\% Cl]

Collins et al 2007

Huffman et al 2013

Metlen and Fiedler 2006

Nelson et al 2008

Waldrop et al 2008 (GR)

Waldrop et al $2008(\mathrm{OH})$

Zhang et al 2008
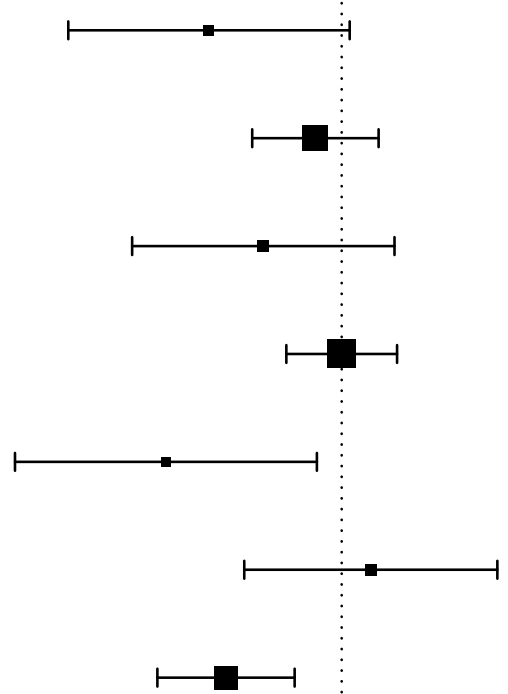

$-1.42[-2.92,0.09]$

$-0.28[-0.96,0.39]$

$-0.84[-2.24,0.56]$

$0.00[-0.59,0.59]$

$-1.88[-3.49,-0.26]$

$0.31[-1.04,1.66]$

$-1.24[-1.97,-0.50]$

RE Model

$-0.59[-1.05,-0.14]$

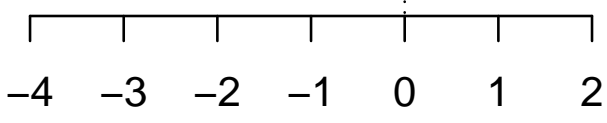

Standardized Mean Difference 
Nelson et al 2008

Metlen and Fiedler 2006

2009 (SL)

Mason et al 2009 (CO) -

Mason et al 2009 (BA) -

Huffman et al 2013

Collins et al 2007

Waldrop et al $2008(\mathrm{OH})-$
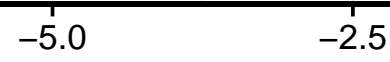

0.0

2.5

Totol cover Thin - Control Hedge's g 